\title{
The Relationship between Stunting and Tooth Eruption of Primary School Children at Tuah Negeri Sub-district, Musi Rawas District, South Sumatera Province, Indonesia
}

\author{
${\text { Mohammad Zulkarnain }{ }^{1 *} \text { (D), Rico Januar Sitorus }}^{2}$ D , Yeni Anna Appulembang ${ }^{3} \mathbb{D}$, Annisah Biancika Jasmine $^{4}$, Abubakar Lutfi $^{4}$ \\ ${ }^{1}$ Department of Public Health Science, Faculty of Medicine, Sriwijaya University, Palembang, Indonesia; ${ }^{2}$ Department \\ of Epidemiology, Faculty of Public Health, Sriwijaya University, Palembang, Indonesia; ${ }^{3}$ Psychology Study Program, Faculty \\ of Medicine, Sriwijaya University, Palembang, Indonesia; ${ }^{4}$ Public Health Science Study Program, Faculty of Public Health, \\ Sriwijaya University, Palembang, Indonesia
}

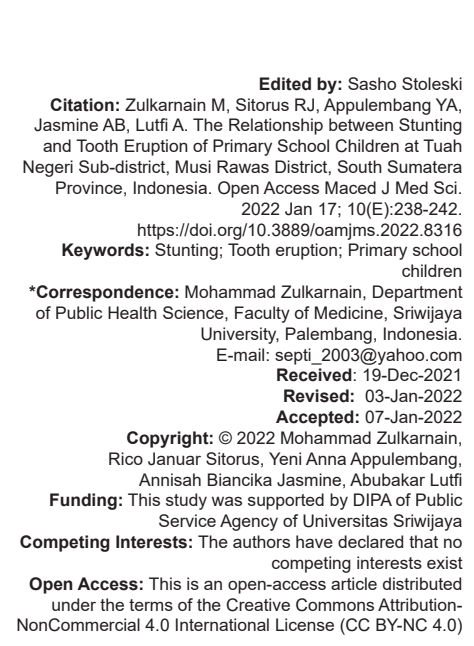

\section{Background}

Stunting is a condition where the body height is shorter than normal, unproportioned to the child age, caused by lack of nutrition, and/or caused by repeated disease in a long time period since the development of fetus until the first 2 years of life. Practically, stunting can be detected by measuring body height and weight and then compare it with the standard [1].

In Indonesia, the direct factors for stunting are low birth weight, consumption of low energy and protein food, diarrhea, and upper respiratory tract infection, while the undirect factors are no exclusive breast feeding, incomplete immunization package, and socioeconomic conditions such as parent's education and job status and family economic status [2]. The report from Indonesian Ministry of Health showed that in average the prevalence of stunting in Indonesia in 2005-2017 was $36.4 \%$. Stunting in primary school children aged 5-12 years old was $24.1 \%$ for male and 25.2 for female, respectively [3].

The inadequate growth and development in children with stunting not only affect the body height. Iriyani (2010) studied the relationship between body mass index and first permanent molar tooth eruption among children aged 6-7 years old and Rahmawati et al. (2014) studied the relationship between nutritional status and mandibular permanent central incisor at the same age group showed that children with poor nutritional status had delayed permanent teeth eruption compared to those with good nutritional status [4], [5]. Furthermore, children with stunting condition are more vulnerable for tooth decay because of the change of saliva characteristics in those stunted children [6].

The University of Alabama at Birmingham Health System states that calcium, phosphorus, Vitamin C, and Vitamin D intake are also extremely 
important so that lack of those nutrients can prohibit body growth and tooth development and eruption [7].

This study was conducted in Tuah Negri Sub-district at Musi Rawas District, South Sumatra Province, Indonesia, because Musi Rawas is one of the districts in Indonesia with high prevalence of stunting event, where the stunting prevalence is $34.6 \%$. The District Health Department stated that the high stunting prevalence was caused by low family economic status [8].

\section{Methods}

The research employed a quantitative research design with a cross-sectional analytical survey method. Tooth examination was performed among 94 randomly selected students of five purposively selected primary schools based on their high prevalence of stunting cases. The results were then put into the odontogram. Nutritional status was examined anthropometrically to identify stunting event. Measurements of height and weight were taken by trained health worker from local community health center. In this study, stunting was defined as height-for-age z-score of $<-2$ standard deviation of the National Centre for Health Statistics Reference [9]. The students grouped into stunting and not stunting. Data were analyzed with Chi-square and logistic regression test. Other respondent's characteristics were taken using questionnaire. Calculation of sample size using the survey formula with estimation of stunting among the primary students of $30 \%(p=0.3)$ and precision of 0.1 , gave the minimum sample size of 81 students to be recruited as respondents.

\section{Ethical approval}

This research has received ethical approval from the Ethics Commission of the Faculty of Public Health, Sriwijaya University, No.154/UN9.FKM/ TU.KKE/2021, and the collection of data was conducted after an informed consent process had been done.

\section{Results}

The characteristics of respondents are shown in Tables 1 and 2.

There were 31 children with stunting $(33.0 \%$ of respondents) and 21 of those with the stunting (67.7\%) were identified as having delayed tooth eruption.
Table 1: Frequency distribution of elementary school students' characteristics based on stunted and not stunted

\begin{tabular}{|c|c|c|c|c|c|c|}
\hline \multirow[t]{2}{*}{ Frequency distribution } & \multicolumn{2}{|c|}{ Stunted } & \multicolumn{2}{|c|}{ Non-stunted } & \multicolumn{2}{|c|}{ Total } \\
\hline & $\mathrm{n}$ & $f(\%)$ & $\mathrm{n}$ & $f(\%)$ & $\mathrm{n}$ & $f(\%)$ \\
\hline \multicolumn{7}{|l|}{$\mathrm{Age}^{*}$} \\
\hline 9-10 years old & 14 & 40.0 & 21 & 60.0 & 35 & 100 \\
\hline 11-12 years old & 17 & 28.8 & 42 & 71.2 & 59 & 100 \\
\hline \multicolumn{7}{|l|}{ Gender $^{\#}$} \\
\hline Female & 22 & 42.3 & 30 & 57.7 & 52 & 100 \\
\hline Male & 9 & 21.4 & 33 & 78.6 & 42 & 100 \\
\hline \multicolumn{7}{|l|}{ Father's education* } \\
\hline Low & 25 & 32.9 & 51 & 67.1 & 76 & 100 \\
\hline High & 6 & 33.3 & 12 & 66.7 & 18 & 1.00 \\
\hline \multicolumn{7}{|l|}{ Mother's education* } \\
\hline Low & 24 & 32.4 & 50 & 67.6 & 74 & 100 \\
\hline High & 7 & 35.0 & 13 & 65.0 & 20 & 100 \\
\hline \multicolumn{7}{|l|}{ Father's occupation* } \\
\hline Farmers & 15 & 29.4 & 36 & 70.6 & 51 & 100 \\
\hline Others & 16 & 37.2 & 27 & 62.8 & 43 & 100 \\
\hline \multicolumn{7}{|l|}{ Mother's occupation" } \\
\hline Farmers & 29 & 34.1 & 56 & 65.9 & 85 & 100 \\
\hline Others & 2 & 22.2 & 7 & 77.8 & 9 & 100 \\
\hline \multicolumn{7}{|l|}{ Parent's income ${ }^{*}$} \\
\hline$\leq 1,000,000$ & 19 & 32.2 & 40 & 67.8 & 59 & 100 \\
\hline$>1,000,000$ & 12 & 34.3 & 23 & 65.7 & 35 & 100 \\
\hline
\end{tabular}

There was no significant difference on the proportion of children with stunting event based on age, father's education, mother's education, father's occupation, mother's occupation, and parent's income, but there was a significant difference on the proportion of children with the stunting event based on the gender. The proportion of children with stunting was significantly higher among female compared to male $(p=0.032$, odds ratio $[\mathrm{OR}]=2.7[95 \%$ C.I. $=1.1-6.7])$. It suggests that female primary school children with stunting have 2.7 times higher possibility to be stunted compared with male primary school children.

Table 2: Frequency distribution of elementary school students' characteristics based on tooth eruption status

\begin{tabular}{|c|c|c|c|c|c|c|}
\hline \multirow[t]{2}{*}{ Frequency distribution } & \multicolumn{2}{|c|}{ Delayed } & \multicolumn{2}{|c|}{ Not delayed } & \multicolumn{2}{|c|}{ Total } \\
\hline & $\mathrm{n}$ & $f(\%)$ & $\mathrm{n}$ & $f(\%)$ & $\mathrm{n}$ & $f(\%)$ \\
\hline \multicolumn{7}{|l|}{ Age } \\
\hline $9-10$ years old & 18 & 51.4 & 17 & 48.6 & 35 & 100 \\
\hline $11-12$ years old & 31 & 52.5 & 28 & 47.5 & 59 & 100 \\
\hline \multicolumn{7}{|l|}{ Gender } \\
\hline Female & 28 & 53.8 & 24 & 46.2 & 52 & 100 \\
\hline Male & 21 & 50.0 & 21 & 50.0 & 42 & 100 \\
\hline \multicolumn{7}{|l|}{ Father's education } \\
\hline Low & 44 & 57.9 & 32 & 42.1 & 76 & 100 \\
\hline High & 5 & 27.8 & 13 & 72.2 & 18 & 1.00 \\
\hline \multicolumn{7}{|l|}{ Mother's education } \\
\hline Low & 41 & 55.4 & 33 & 44.6 & 74 & 100 \\
\hline High & 8 & 40.0 & 12 & 60.0 & 20 & 100 \\
\hline \multicolumn{7}{|l|}{ Father's occupation } \\
\hline Farmers & 23 & 45.1 & 28 & 54.9 & 51 & 100 \\
\hline Others & 26 & 65.0 & 17 & 39.5 & 43 & 100 \\
\hline \multicolumn{7}{|l|}{ Mother's occupation } \\
\hline Farmers & 45 & 52.9 & 40 & 47.1 & 85 & 100 \\
\hline Others & 4 & 44.4 & 5 & 55.6 & 9 & 100 \\
\hline \multicolumn{7}{|l|}{ Parent's income } \\
\hline$\leq 1,000,000$ & 34 & 57.6 & 25 & 42.4 & 59 & 100 \\
\hline$>1,000,000$ & 15 & 42.9 & 20 & 57.1 & 35 & 100 \\
\hline
\end{tabular}

The study showed that there were 49 children $(52.1 \%)$ suffered experienced delayed tooth eruption and 45 students without it.

There was no significant difference on the proportion of children with delayed tooth eruption based on age, gender, mother's education, father's occupation, mother's occupation, and parent's income, but there was a significant difference on the proportion of children with delayed tooth eruption based on father's education. The proportion of children with delayed tooth 
eruption was significantly higher among children with low educated fathers compared to children with high educated fathers $(p=0.021$, OR $=3.6[1.2-11.0])$ (Table 3).

Table 3: Association between nutritional and tooth eruption in primary school children

\begin{tabular}{|c|c|c|c|c|c|c|c|c|}
\hline \multirow[t]{2}{*}{ Frequency distribution } & \multicolumn{2}{|c|}{ Delayed } & \multicolumn{2}{|c|}{ Not delayed } & \multicolumn{2}{|c|}{ Total } & \multirow{2}{*}{\multicolumn{2}{|c|}{$\mathrm{p} \quad \mathrm{OR}$}} \\
\hline & $\mathrm{n}$ & $f(\%)$ & $\mathrm{n}$ & $f(\%)$ & $\mathrm{n}$ & $f(\%)$ & & \\
\hline Stunted & 21 & 67.7 & 10 & 32.3 & 31 & 100 & 0.034 & $2.63(1.7-6.5)$ \\
\hline Not-stunted & 28 & 44.4 & 35 & 55.6 & 63 & 100 & & \\
\hline
\end{tabular}

Statistical examination using Chi-squared test showed that the proportion of children with delayed tooth eruption was significantly higher among children with stunting compared to those without stunting, with $p=0.034$ and OR $2.63(95 \%$ C.I. $=1.7-6.5)$.

\section{Multivariate analysis}

The multivariate analysis was performed to assess which variables that can be used to predict the probability of a child to experience delayed tooth eruption based on those predictor variables. The result is listed in Table 4.

Table 4: Regression model for predicting tooth eruption in primary school children

\begin{tabular}{lllllllll}
\hline Variables & B & S.E. & Wald & Df & Sig. & Exp (B) & \multicolumn{2}{l}{ 95\% C.I. for Exp(B) } \\
\cline { 6 - 9 } & & & & & & & Lower & Upper \\
\hline Fathers education & 1.354 & 0.595 & 5.172 & 1 & 0.023 & 3.872 & 1.206 & 12.435 \\
Stunted & 1.037 & 0.480 & 4.664 & 1 & 0.031 & 2.820 & 1.101 & 7.227 \\
Constant & -1.351 & 0.578 & 5.464 & 1 & 0.019 & 0.259 & & \\
\hline
\end{tabular}

Logistic regression analysis showed that there were two variables that can be used to predict the probability for a child in Tuah Negeri sub-district at Musi Rawas district, South Sumatra Province, Indonesia, to experience delayed tooth eruption, which were father's education and stunting condition. Children with low educated fathers have the probability of 3.87 times higher to experience delayed tooth eruption than children with low educated fathers. Children with stunting condition have the probability of 2.82 times higher to experience delayed tooth eruption than children without stunting condition.

Furthermore, Table 5 showed that the logistic regression model can correctly predict $60.6 \%$ of the delayed tooth eruption cases among respondents in this study.

Table 5: Classification table for predicting the tooth eruption in primary school children

\begin{tabular}{llll}
\hline Observed & \multicolumn{2}{l}{ Predicted not delayed } & Percentage \\
\hline Not delayed & 13 & 32 & 28.9 \\
Delayed & 5 & 44 & 89.9 \\
Overall Percentage & 18 & 76 & 60.6 \\
\hline
\end{tabular}

\section{Discussion}

We found that the percentage of primary school children with stunting was $33.0 \%$, which is higher than the 2017 national data which were $24.1 \%$ for male primary school children and 25.2 for female primary school children, respectively [3]. Moreover, it was also higher than the provincial level prevalence data which were $22.8 \%$ in 2017 [10]. This is may be partly related to the low economic condition of most of the household in this working area of Air Beliti Community Health centre, because in 2015, this district was declared by the government of Indonesia as one of under-developed districts in Indonesia. A study on stunting among under-five children in coastal area of Kendal district found that there was significant relationship between stunting and parent's characteristics [11], especially for the children who lived in a big size family with low purchasing power [12].

The study showed that there were 49 children $(52.1 \%)$ suffered experienced delayed tooth eruption and 45 students without it. In general, delayed tooth eruption can be caused by endocrine such as hypothyroidism, hypoparathyroidism, hypopituitarism, nutritional disorder, and several systemic diseases [13]. The systemic diseases that can cause the delay tooth eruption such as hemifacial hypertrophy and odontomaxillary dysplasia, cleidocranial dysplasia, down syndrome, achondroplastic dwarfism, trichodento-osseous-syndrome, pycnodysostosis, and pituitary gigantism [13], [14]. For this study, permanent teeth trauma, teeth illness, endocrine disorder, and systemic diseases were part of exclusion criteria during the sample recruitment process so that the discovered delayed tooth eruption was considered as the result of children's nutritional factor.

The study found that $67.7 \%$ of than stunted children were suffered delayed tooth eruption.

The proportion of children with delayed tooth eruption was significantly higher among children with low educated fathers compared to children with high educated fathers $(p=0.021$, OR $=3.6[1.2-11.0]$ ). This finding was in accordance with the result of Putri et al. who supposed that parents with low education level had inadequate information on child care, child health maintenance, and food consumption habit [15]. Low educated parents will have less ability to provide enough nutritious food to their children and become more possible to be stunted children with delayed tooth eruption [11], [16].

We also found that the proportion of children with delayed tooth eruption was significantly higher among children with stunting compared to those without stunting, with $p=0.034$ and OR 2.63 (95\% C.I. $=1.7-$ $6.5)$, the result suggested that there was an association 
between stunting and delayed tooth eruption among primary school children. The OR of 2.63 indicated that children with stunting condition have 2.63 times higher possibility to experience delayed tooth eruption compared with those without stunting. Children with good nutritional status experience their tooth eruption earlier than those with poor nutritional status. This is in accordance with the result from Windratih who found that there was a significant association between nutritional status and the eruption of permanent teeth among primary school children in Manado, Indonesia. The eruption of permanent teeth of children with normal nutritional status, obese, and severely obese was in line with their eruption age, while stunted children had delayed permanent teeth eruption [17]. Lack of nutrition delay bone growth including the maturation of periodontal bone which supports the children's tooth eruption process [18]. As the results, the eruption of permanent teeth of under-five children with stunting condition was significantly lower compared with the eruption of normal under-five children [19].

Logistic regression analysis showed that there were two variables that can be used to predict the probability for a child in Tuah Negeri sub-district at Musi Rawas district, South Sumatra Province, Indonesia, to experience delayed tooth eruption, which were father's education and stunting condition, but the model can only correctly predict $60.6 \%$ of the delayed tooth eruption cases among the respondents. These suggests are other variables that need to be added into the model to increase the accuracy of the model so that practically it is appropriate to be employed.

\section{Conclusion}

There was a significant association between stunting and delayed tooth eruption among primary school children. Children with stunting condition have 2.63 times higher possibility to experience delayed tooth eruption compared with those without stunting. Stunting condition and father's educational status together can be used to predict the probability for a child to experience delayed tooth eruption, but other variables need to be added into the model to increase the accuracy of the model.

\section{Acknowledgment}

This research of this article was funded by DIPA of Public Service Agency of Universitas Sriwijaya. SP DIPA-023.17.2.677515/2021, on
November 23, 2020. In accordance with the Rector's Decree Number: 0010/UN9/SK.LP2M.PT/2021, on April 28, 2021. The authors gratefully acknowledge those who had contributed their generous support in completing this work.

\section{References}

1. WHO. Nutrition Landscape Information System (NLIS) Country Profile Indicators: Interpretation Guide. Geneva: World Health Organization; 2010.

2. Bappenas. National Action Plan of Food and Nutrition 2011-2015 [Rencana Aksi Nasional Pangan dan Gizi 20112015]; 2011. Available from: https://www. bappenas.go.id/ files/4613/5228/2360/ran-pg-2011-2015.pdf [Last accessed on 2021 Dec 17].

3. Indonesian Ministry of Health [Kementerian Kesehatan RI] Pocket Book for Nutritional Status Monitoring Year 2017 [Buku Saku Pemantauan Status Gizi Tahun 2017]. Jakarta: Indonesian Ministry of Health; 2018.

4. Iriyani S. Association between body mass index and upper and lower jaw first permanent molar tooth eruption in children 6-7 years old age in makassar perumnas II primary school year 2009 [Hubungan antara indeks massa tubuh dengan erupsi gigi molar pertama permanen rahang atas dan rahang bawah anak umur 6-7 tahun di SD inpres perumnas II makassar tahun 2009]. Dental Health Med. 2010;1:24-7.

5. Rahmawati, $A D$, Retriasih $H$, Medawati $A$. The relationship between nutritional status and the status of the eruption of permanent mandibular central incisors [Hubungan antara status gizi dengan status erupsi gigi insisivus sentralis permanen mandibula]. Insisiva Dent J. 2014;3(1):16-21.

6. Abdat M, Usman $\mathrm{S}$, Chairunas, Suhaila H. Relationship between stunting with dental and oral status in toddlers. J Dentomaxillofac Sci. 2020;5(2):114-9

7. The University of Alabama at Birmingham UAB Health System. Anatomy and Development of the Mouth and Teeth; 2004 Available from: http://www.uabhealth.org/14134 [Last accessed on 2021 Jan 20]

8. South Sumatra Province Health Department [Dinas Kesehatan Provinsi Sumatera Selatan]. South Sumatra Province Health Profile Year 2017 [Profil Kesehatan Provinsi Sumatera Selatan tahun 2017]. South Sumatra: South Sumatra Province Health Department; 2018.

9. WHO. Multicentre Growth Reference Study Group. WHO Child Growth Standards: Length/Height-for-Age, Weight-Forage, Weight-for-Length, Weight-for-Height and Body Mass IndexFor-Age: Methods and Development. Geneva: WHO; 2006.

10. Indonesian Ministry of Health [Kementerian Kesehatan RI]. Data Window Bulletin and Health Information: Stunting among Under-Five Children Situation in Indonesia [Buletin Jendela Data dan Informasi Kesehatan: Situasi Balita Pendek (Stunting) di Indonesia], Semester I. Jakarta: Pusdatin Kemenkes; 2018.

11. Utami AP. Association between Family Economy and Stunting Event among Under-Five Children 12-59 Months Old in Coastal Area Kendal Province, Semarang [Hubungan Sosial Ekonomi Keluarga Dengan Kejadian Stunting pada Anak Balita 12-59 Bulan di Daerah Pesisir Kabupaten Kendal]. Semarang: Universitas Diponegoro; 2013.

12. Sulastri D. Stunting determinant factors in primary school age children in Lubuk Kilangan sub-district Padang city 
[Faktor determinan kejadian stunting pada anak usia sekolah di Kecamatan Lubuk Kilangan Kota Padang]. Andalas Med Magazine. 2012;36(1):39-50.

13. Lawler W, Ahmed A, Hume WJ. In: Bahasa A, Djaya A, Yuwono L, editors. Essential Pathology for Dental Students [Buku Pintar Patologi Untuk Kedokteran Gigi]. Jakarta: EGC; 2002.

14. Schuurs AH. In: Bahasa A, Sutatmi S. Pathology of The Hard Dental Tissues [Patologi Gigi-Geligi Kelainan-Kelainan Jaringan Keras Gigi]. Yogyakarta: Gadjah Mada University Press; 1992.

15. Putri RM, Maemunah N. Relation of Education, parent's occupation with pre-school children's nutritional status [Kaitan pendidikan, pekerjaan orang tua dengan status gizi anak pra sekolah]. Care J IIm IImu Kesehatan. 2017;5(2):231-45.

16. Lestari W, Rezeki SH, Siregar DM, Manggabarani S. Factors related to stunting event in 014610 government primary school children in Sei. Renggas Kisaran Barat sub-district, Asahan district [Faktor yang berhubungan dengan kejadian stunting pada anak sekolah dasar Negeri 014610 Sei Renggas Kecamatan Kisaran Barat Kabupaten Asahan]. J Dunia Gizi. 2018;1(1):59-64.

17. Lantu VA, Kawengian SE, Wowor VN. Association between nutritional status with permanent tooth eruption in the number 70 government primary school students in manado [Hubungan status gizi dengan erupsi gigi permanen siswa SD negeri 70 manado]. e-GiGi. 2015;3(1):189-96.

18. Stegeman CA, Judi RD, Linda DB. The Dental Hygienist Guide to Nutritional Care. $3^{\text {rd }}$ ed. Missouri: Saunders; 2005.

19. Triyanto R, Nugroho C, Miko H. Permanent tooth eruption in under-five children in Tamansari district Tasikmalaya city [Erupsi gigi sulung pada balita stunting di Kecamatan Tamansari Kota Tasikmalaya]. Actual Res Sci Acad. 2016;1(1):29-32. 